\title{
CHARACTER EDUCATION IN ISLAMIC BOARDING SCHOOL- BASED SMA AMANAH
}

\section{Nana Herdiana Abdurrahman}

State Islamic University (UIN) Sunan Gunung Djati Bandung, Indonesia. Jl. A. H. Nasution No. 105, Bandung, West Java-Indonesia

Email: nanaherdiana.uinbdg@gmail.com

\begin{abstract}
This paper aims to describe findings of the study in pesantren-based SMA Amanah covering: 1) the principal policy in developing character education, 2) the methods used in developing character education, 3) students' characteristics as the result of the character education process, 4) the problems encountered in the implementation of character education and the efforts made in addressing the implementation of character education at the school. This study applied qualitative method using descriptive technique. The data were collected through observation, interviews, and documentation. The findings of study showed that: 1) the principal's policy in developing character education was carried out by implementing government policies in line with the school's vision, mission, and programs; 2) the methods used in the process of character education were through role-modeling, assignments and nurturing, habituation, training programs, and students' participation in various types of activities, as well as the application of rewards and punishments; 3) the student's characteristics resulted from the character education process were piousness and devotion as well as being able to apply their knowledge and piety in everyday life; 4) problems encountered in the implementation of character education were different values and norms students brought from home; imbalance of facilities compared to the number of students; as well as teachers' readiness to actually implement the new program, which was character education. Meanwhile the efforts made to overcome those problems were namely developing personal, family, neighborhood or community characters, and making commitment of all related parties/stakeholdres of SMA Amanah.
\end{abstract}

Keywords: Character Education, Boarding School, Value.

\section{ABSTRAK}

Tulisan ini bertujuan untuk. memperoleh informasi tentang: kebijakan kepala sekolah, metode yang digunakan, karakter siswa, dan masalah yang dibadapi serta upaya yang dilakukan dalam penyelenggaraan pendidikan karakter di SMA berbasis pesantren. Penelitian menggunakan metode deskriptif dengan pendekatan kualitatif. Prosedur pengumpulan data yang digunakan melalui observasi, wawancara, dan dokumentasi. Hasil penelitian menunjukkan babwa: 1) kebijakan kepala sekolah dalam pengembangan pendidikan karakter mengacu pada visi, misi serta program sekolab; 2) metode yang digunakan dalam proses pendidikan karakter dilakukan melalui keteladanan, melalui penugasan dan pengasuban, melalui pembiasaan, melalui program pelatihan, dan melalui partisipasi santri dalam berbagai jenis kegiatan, serta melalui penghargaan dan bukuman; 3) karakter siswa hasil proses pendidikan adalab siswa yang beriman dan 
bertaqwa serta mampu mengaplikasikan ilmu dan ketaqwaannya ke dalam perilaku sehari-hari; 4) masalah yang dihadapi dalam penyelenggaraan pendidikan karakter di antaranya adalah perbedaan nilai dan norma bawaan siswa tersebut, tidak seimbangnya fasilitas dengan jumlah siswa, serta pendidikan karakter merupakan program baru sebingga beberapa guru masib perlu melakukan penyesuaian-penyesuian; serta upaya yang dilakukan dalam mengatasi masalah penyelenggaraan pendidikan karakter di SMA berbasis pesantren di antaranya membangun karakter diri, karakter keluarga dan karakter lingkungan sekitar atau masyarakat serta membangun sebuah komitmen semua pibak yang terlibat.

Kata Kunci: Pendidikan Karakter, Sekolah Berasrama, Nilai.

\section{INTRODUCTION}

In a society where there is degradation of values and morality, it is the right moment to revive character education. Public's support to its implementation in schools is clearly expressed. Evidences suggest that the implementation of character education in educational institutions enables them to build better school culture, provide better safety for students, as well as helping them to concentrate in learning so that their achievement increases. This transformation process is likely to occur when all stakeholdres involved in the work of education strive to apply the basic values of character education. It could be done by modeling good behavior in all dimensions/school facilities including cafeteria, classrooms, gyms, labs, school buses, and so on.

In the contemporary context, strengthening character education is very relevant to address the moral crisis happening in our country. The current social crisis is very real and alarming as it is concerning our children. One of the mostalarming is the increase of juvenile delinquency. Bandung Police Department (Polwiltabes Bandung) record of juvenile delinquency increased by 13\% in 2011 compared to 2010 as reported by Detik.com. They are as follows:

1) The number of homicide among teenagers in 2010 was 86 cases, while there were 64 cases in 2011 (decreased by 25.58\%); 2) The number of sexual abuse among adolescents was 60 cases in 2010, and 68 cases in 2011, (increased by 13.33\%); 3) The number of theft and violence among adolescents was 931 cases in 2010, and 895 cases in 2011 (decreased by 3.86\%); 4) The number of thefts among teenagers was 6048 cases in 2010, and as many as 6007 cases in 2011 (decreased by $12.54 \%)$; 5) The number of abuse among adolescents was 1937 cases in 2010, and as many as 1936 cases in 2011 (decreased by $0.05 \%$ ); 6) The number of drug abuse among teenagers was 4989 cases in 2010 and 4694 cases in 2011.

This kind of moral degradation also happens to adults as many of them seem enjoying conflict and violence or clashes, corruption is rampant, and 
infidelity becomes a common thing. As described by Zuhdi (2009, p. 39-40), there are seven moral crises occurring among the people of Indonesia at this time including crisis of honesty, responsibility, discipline, justice, togetherness crisis and inability to think wisely.

This condition is allegedly resulted by education where demoralization happens because the learning process tends to focus the moral and character education only on textual level without actually preparing the students with skills to face challenges and contradictions in life. The existing crisis and moral decadence indicate that all religious and moral knowledge acquired in school do not have an impact on the change of human behavior in Indonesia. Even worse, many Indonesian people tend to be hypocrite where they do not do what they say or say what they do.

Currently, there is a tendency that the academic targets are still the main objectives of education. One of them is the National Examination (UN). This condition makes character education becomes more challenging. The process of developing potential aspects that appreciates students' multiple intelligences such as humility (taw âdlu'), honesty (shiddîq), trustworthy (amânab), intelligent (fathânah) and teaching (tabligh) as forms of moral virtue receive less attention. As described by Koesoema in Zubaedi (2012, p. 3): "the society's and government's commitment to integrate education and character building is the weak point of the national education system. Therefore, all parties should agree to work together in tackling this moral decadence. Doctors, policy makers, religius leaders, enterpreneurs, educators, parents and the society, all have the same concern about this condition.We do have to worry because shocking tragedy and statistics regarding crisis in the youth are everywhere in the news. Therefore, we must strive to find the solutions to these problems.

Instead of addressed as moral education which involves realized and actual virtues, the process of character education prioritizes the process of the value and attitude internalization to develop good characters. The values in this sense are the ones that help people to learn to leave together. They are related to various aspects of life such as people's relationships, personal life (learning to be), statehood, worldly life, and the preparation of afterlife.

Pesantren (boarding school) is a place where students and Islamic teacher/kyai or his representative learn formally, non-formally, and informally whether in the morning, at noon, or in the evening. Pesantren has been proven successful in educating their students and creating charismatic and high quality scholars and religious leaders. It is due to their effective teaching methods they develop in which focusing on personal guidance by the kyai (teachers) and students' qualitative comprehension instead of merely the cognitive aspects through lecturing. It also prioritizes students' moral and 
spiritual aspects. In addition, it also trains and enhances students' attitudes of appreciating spiritual and humanity values, instills good behaviors such as honesty, morality as well as preparing them to recognize religious ethics and put it above the others.

Based on the explanation above, regarding the importance of implementing character education in school, the researcher conducted a study of the implementation of character education in islamic boarding school/pesantren-based SMA Amanah in order to investigate: 1) the principal's policy in developing the character education at the school, 2) the methods used in the process of character education, 3) Students characteristics resulted from the character education process, 4) the problems encountered in the implementation of character education and the school's efforts to overcome them.

This study applied descriptive analytical method. It refers to a method of study that emphasizes on obtaining information about the subject status or condition at the time of the study, provides descriptions of the phenomena, and explains the relationships found, as well as to draw conclusion about the situation under investigation.

\section{FINDINGS AND DISCUSSION}

\section{The Principal's Policy in Developing Character Education Implemented in Pesantren-Based SMA Amanah}

The Principal policy in developing character education for the students was to integrate some elements of the existing curricula, namely, the national curriculum, Gontor curriculum and salafiyah curriculum. These three curriculums served as bases aimed at eliminating the dichotomy between science of qauliyyah (Al quran) and science of kauniyyah (Universe).

Each curriculum has its own emphasis; the national curriculum emphasizes on its classical system, while Gontor and salafiyyah underscore sorogan and bandungan systems. The implementation of the curriculums was not solely intra-curricular, but they also involved all school activities including co-curricular and extra-curricular activities. As mentioned above, these activities are organized into daily, weekly, semi-annual and annual acivities in the school academic program.

The policies regarding the context of character education are implemented in accordance with the school's vision and missions. The program in terms of knowledge and its practice was integrated to daily life in the dormitory. Other supporting policy was structured and programmed spiritual activities (hablum minallah) through the role of kyai. To realize this, the school requires the students to learn to be independent and to develop their potentials with the guidance from their advisors. 
The schools applied semi-modern management in various lines. Setting Arabic and English as official languages to be used in daily communication is among other things. In addition, the principal's policies were also associated with local and global-based education such as memorizing alquran/tahfǐ life skills, Islamic law study/Diniyah, intensive arabic program/Takhashshush Arabic (TBA) and the program of Kbidmah/students' services.

The Policies of character education development involved several activities related to the learning process either intra or extracurricular as follows: (a) The increased number of hours for religious education lessons from two to six hours per week; (b) strict rules in both school and dormitory wherepunishment and reward system was applied; (c) Internalization of personal maturity and independency by learning to clean the environment both indoors and outdoors; (d) Additional learning time by letting students to do self-study, as well as to memorize the holy verses of alQuran; (e) Exposure to Arabic and English aimed for the students to write and have speech in both foreign languages

The findings show that the principal policies in implementing character education in SMA Amanah was in line with the strategic plan, namely the vision, mission and goals of the school. The most strategic policy offered by the principal was creating conducive learning environment that meets the six valuesof life: theological, physiological, ethical, aesthetical, logical and teleological values. However, the policies implemented to develop character education still require further study, standardized method, guidance, as well as consistent and effective controlling.

The principal policies in developing character education can be broadly categorized into obligatory and optional extracurricular programs such as annual meeting at the beginning of every school year to arrange the school rules. It is then actualized by daily, weekly, monthly and annual programs. The results were then evaluated by statistics of reward and punishment given. The school classified violations into: light violation, including coming late for prayer congregation, playing around in the mosque, wearing inapropriate clothes, expressing inapproriate words/language, not wearing Islamic hat (peci); and intermediate violation, including learning half day, sleeping in dormitory during class hour, and not joining the obligatory extracurricular activities.

\section{Method Used in Character Education Process}

SMA Amanah applied the so-called total eduation. It is carried out by role-modeling, environment conditioning, guiding, habituation and taskgiving. Therefore, every single thing that students see, listen, feel and do is a 
part of education. In addition to role-modeling as the primary method of education, environment conditioning is also essential. It is done through assignment, habituation, training, teaching and guidance for students. All students have experienced leading and being in an activity as well as learning from the assignments. Findings gained from the observation, interviews and documentation in the implementation of character education could be seen as follows:

1. Character Education through Role-modeling

Some exemplary actions brought into habit: a) disciplined worship activities. This habit was modeled by Kyai or ustâdz punctuality to come to the mosque. Students were expected to arrive 20 minutes before prayer time. b) Guidance on amr ma'rûf nabyi munkar (command on deed and prohibition on evil). This method reinforced students's effort to act as exemplified by the kyai.

2. Character Education through Assignment and Nurturing

Educational pattern in the school referred to two schemas: nurturing and teaching. Nurturing referred to students' education regarding all the activities and life outside of school hours (in the dormitory). Meanwhile, teaching referred to students' activities at school. Student nurturing had a controlling function in the first schema. Basically, both the intra- and extracurricular activities complement and integrated with each other in order to support character education.

3. Character Education through Habituation

As students started studying, they entered a new atmosphere. They (including new students) had to get used to perform and apply their knowledge in everyday life. They should get in touch and familiarized with the activities in school and life in the dormitory which in turn supported the environment conditioning for them to live in.

4. Character Education through Training Programs

All students must actively participate in extracurricular activities, either the mandatory such as the scouts, public speaking/mubâdlarah and conversation/mubaddatsah or or the optional ones such as cooperatives, various sport activities, arts, and so forth. They could actively involved as members or even committee of each organization as it was intended to become a place for them to train their life skills before getting involved in the society.

5. Character Education through Student's Participation in Various Activities

Pesantren provided options for students to be actively involved in curricular and extracurricular activities. However, once a student made the choice to be active in a particular activity, he ought to wholeheartedly engage 
in the activity, regardless the role he plays in the organization. Teachers would always support them to live life to the fullest as well as reminding them to socialize well.

6. Character Education through Reward and Punishment

Another essential method of character education was the application of reward and punishment system. It was aimed at giving best performer a reward and punishing student violating rules or leaving their obligations. All student activities were evaluated and the result was announced. This method is applied as fairly as possible in accordance with students' achievements or mistakes so that they would feel treated fairly and valued for their existence and behavior. The objective of this method was to educate students to be responsible on every act and decision they make in their life.

The character education applied at the school through modeling from Kiai, teachers and senior students. This method should be carried out continuously so that students' hearts would incline toward God, as explained by Imam Al Ghazali (1994, p.142):

If you watch attentively, your heart will open and you will see all evil feelings, the causes and the cures, which are knowledge and faith. If you are weak in this, you are not supposed to leave your faith and piety by seeing and following, for those who have the right to.

Character building through nurturing and habituation are embodied in the education system in boarding schools for 24 hours, starting from waking up to the time they go to bed. Imam Al-Ghazali (1994, p. 136) explains that teachers should set an example to his students so that they could get used to behave in accordance with the expected norms, namely by: Familiarizing himself to courtesy and anger management. He then asked and paid someone to insult him in public, and he forced himself to hold his anger so courtesy could become his default act. It eventually made him a role model for others.

Teachers who live 24 hours with the students, as stated by Al Ghazali (1994, p. 134) are obliged to guide and "concerned about the students' condition, their illness, age, as well as their body nature and capacity". Furthermore, he revealed that:

"If students are in their begining stage of learning, where they do not know yet about the rules and obligations of the religion, the first thing to teach them is the knowledge and practice of purification, prayer and physical religious practices. If they are trapped or involved in baram wealth, or they commit unlawful act, they should be ordered to first leave them.

Pesantren has educational totality by counting on role modeling, environment conditioning, and habituation through tasks and activities. Therefore, everything students see, hear, feel, and do in the boarding school 
is a part of education. Every single thing in the environment contributes to build students' character. Assigning students a particular task should be accompanied with an understanding of the basic philosophy, so that they will do it with awareness and true calling.

Character education through reward and punishment is also implemented at the school. Those who are intelligent and show good attitudes, noble character, and integrity are awarded scholarships or given a chance to lead an organization or activity. It also applies to senior students who are supposed to be able to lead and perform better than their predecessor in terms of positive accomplishments and achievements.

On the implementation of character education, Imam Al Ghazali (1994, p. 134) suggests:

If a student look stubborn, arrogant and too proud of himself, tell him to go to a market and be a beggar. The nature of arrogance and pride will not cease unless by doing a self-debasement.

The integration of all these models for character education is proven successful in building students' strong character. Many graduates of Islamic boarding school become sucessful figures in many fields including government, business, society, and many more.

To train students to control their lusts, Imam Al Ghazali (1994, p. 135) suggests that: When he finds himself greedy of food, he surely needs to fast and eat less. He then needs to train himself to provide delicious food and serve it to others, even though he himself does not eat that food. This habit could help control himself, make him more patient, and eventually destroy his greed.

The character education process in pesantren-based SMA Amanah was in accordance with the theory put forward by Sanusi (2011, p. 14), which states that the right method for character education is learning through rolemodeling, nurturing, habituation, training, participation in activities and learning through reward or punishment. These six methods of character education were actually applied in pesantren-based SMA Amanah.

Character refers to someone's nature growing and developing together with temper. Character and temper are something a person has since he was born. What distinguishes character from temper is that the former could still be changed depending on the process of education he has been through in life. Meanwhile, the latter could never be changed ever. Both would be visualized or expressed in his life in the form of personality. Therefore, the school principal warned students to be careful in choosing friends to hang out with, in order to establish and maintain the good character, as advised by Imam Al Ghazali (1994, p. 144): 
Man needs to find true friends with good heart and strong religious belief, ask them to guide and correct him, to warn him about actions and consequences. So, whatever characteristics, behaviors, and weaknesses he has, both physical and mental, they might tell him.

\section{Students' Characteristics Resulted from Character Education Process in SMA Amanah}

Based on the information collected through interview, observation and documentation, it is found out that virtues are always forged and inculcated in the educational process, either in family, in community or at school. It is eventually expected that the school implementing character Education would creates the nation's future generations who are not only qualified in the field of practical science, but also having good and strong character. It could help keep them from the temptation to abuse their knowledge for negative things. The expected outputs of character education applied at the school are as follows:

\section{Religious Value}

It was expressed in the way the students behave and are obedient in carrying out the teachings of religion. In a more detailed description, the indicators were their habit to pray before and after lessons and opportunities for everyone to practice Islamic teaching.

2. Honesty

Values of honesty could be based on a student behavior to make himself trustworthy in words, actions, and deeds. To foster a culture of honesty, notices with quotes suggesting honesty all over the school were displayed. Character education was implemented in the classroom by being honest and avoiding cheating in quizzes and homeworks. Students were also suggested to participate in organization as a part of education outside the classroom. Competitions on organizational activities were periodically held. It was aimed to train students' responsibility and honesty.

3. Tolerance

Tolerance refers to an act of respecting differences in opinions, attitudes, and actions of others. The indicator was to provide services equally to all class members regardless of their ethnicity, race, class, social status, and economic status. To implement this, the school held many events promoting togetherness and collaboration. The school also did not discriminate any students no matter what views or personal beliefs they show in daily activities.

4. Discipline

The character refers to actions demonstrating orderly behavior and obedience with various rules and regulations. To be more specific, the 
indicators were as follows: in the classroom, students were used to be punctual, comply with rules, wearing proper school uniforms. Regarding the process of character education, students' punctuality is very important.

5. Hardwork

It refers to a behavior indicating earnest efforts to face various challenges of learning and completing tasks. The indicators were: creating an atmosphere of healthy competition, conditioning work ethics, promoting perseverance and persistence in learning, and conditioning a good learning environment. In its implementation, the school promotes activity that require students to compete with their peers. Every activity (sports, arts, or school subjects) was always contested periodically and the results were announced. Other realizations of the character education include tasks given to the students. No matter how difficult the task was, they ought to work hard. In other words, they should not give up before trying as hard as possible.

6. Creativity

It entails thinking and doing something in order to create new ways or modifications of existing things. More detailed indicators were conditioning learning environment that encouraged creative thinking and doing, and giving assignments that challenged students to make new creations or modifications. Character education was also implemented in activities that required students to design their own bedrooms, create handicrafts from recycled materials, make snacks, build models, design a building and hold various events and competitions of education, art, sport, and many others.

7. Independency

It refers to attitudes and behaviors of not depending too easily on others to complete a particular task. The indicator was the conditioning of a learning environment that provides opportunities for students to learn to live independently. Its implementation in the boarding school was making sure that all students are independent. Students were trained to do daily tasks in the dormitory and to meet their personal need such as doing their own laundry, taking a shower, and having meal, and doing their homework independently.

8. Value of Democracy

It refers to the way one thinks, behaves and acts while believing himself to have the same rights and obligations as others. The Indicator was that every decision made was generated through convention and voting. Students elected the organizing committee of their class, scouting team, art group, sport management, as well as the dormitory openly and democratically. All policies applied in the boarding school were made through deliberation and consensus. In its implementation, the school educated students to get used to participating in a variety of events and democratically expressing their ideas. 
This could be seen in the way they discussed and deliberated on an issue as every participants got involved actively, submitted their suggestions and opinions. The school held various activities for this program, namely school board meeting and student board election.

9. Curiosity

It refers to the attitude and actions that requires working to find more depth and breadth of a particular thing. The indicator was that the school provided students a classroom atmosphere that invites curiosity, and programmed environment exploration. Information and communication media was available to facilitate this. its implementation was that the students were stimulated to know many things about science. In other words, learning did not refer solely to textbooks and student worksheets, but it also stimulated learning outside the book, so that students would gain more knowledge. In addition, students were supposed to realize the social situation. To achieve this, students were given a task to find out more about the learning materials in schools by conducting small research, having comparative studies to leading universities and accessing the internet.

10. Nationalism

It refers to the process of stimulating students' nationalism, patriotism, and pride of being Indonesians. The school subject that directly taught the nationalism was about the unity and harmony. In these materials students get learned about scouting. They also learnt the concept of unity through case studies about related problems of the nation of Indonesia. It was expected that they would not get misconception of nationalism. In addition, this value was also internalized by treating students the same way regardless of where they were from.

\section{Patriotism}

It refers to the way of thinking, being, and doing which demonstrate loyalty, care, and high appreciation of national language, physical environment, as well as the social, cultural, economic, and political conditions. Its Implementation was by attaching the photographs of the president and vice president, the national flag, as well as the national symbol in the classroom. In addition, students were also required to attend flag ceremonies, join the scouting team, have speeches in Indonesian language and participate in activities organized by the society around school.

12. Appreciation

It refers to the attitude and actions that drive a person to create something useful for the society, as well as acknowledging and respecting other people's success. Activities that trained students to show appreciation on achievement were as follows: 
a. awarding outstanding students with prizes or certificate of appreciation

b. providing scholarships for outstanding students

c. acknowledging other students with outstanding achievements

13. Friendly or Communicative Value

It refers to the action of showing friendliness and ability to interact and cooperate with others. The indicators were that the school managed classroom setting that facilitated student interactions and dialogical learning. Teachers always listened to students' complaints, and kept a friendly relationship with them. The implementation was that teachers treated students as their partners. Teachers had the role of learning facilitator, so students were encouraged to tell them their problems as it could be seen in the classroom interaction. The friendly and communicative values could be seen from the following activities:

a. the harmony of all members of the school society

b. cooperation in cleaning the dormitory and its surrounding environment

c. ability to have speeches in front of their friends

14. Peace-loving Value

It refers to something a person do, say and act which make other people feel happy and safe in his presence. The indicators at the school were creating a peaceful atmosphere, promoting non-violent behavior and learning to love others. Its implementation was that the teacher created a peaceful learning atmosphere. If students had problem, he would try to handle it by having dialog. To accelerate it, students facilitated to understand the verses of the holy Qur'an about democracy, unity and tolerance. Teachers provided insight to students about the importance of peace. They were also shown the examples in everyday life, including in solving problems in the classroom. Behaviors that showed attitudes, actions of peace could readily be demonstrated by activities such as: the harmony of all members of school society and holding friendly sport matches.

15. Reading Habit

It refers to the habit of sparing time to read various books to get some life lessons and knowledge. The indicators were the availability of list of books or writings that students read, the frequency of library visits, exchange of literature and learning activities which motivate students to seek and use references.

16. Environmental Care

It refers to the attitude and action which seeks to prevent damage of natural environment and develops efforts to repair environmental damage that has 
occurred. The indicators were keeping the boarding school environment, availability of waste management, habituation of energy saving, displaying stickers of notice to turn off the light and close the tap water in every room after use. Its implementation was carried out by internalization of environmental awareness through explanation of the holy Qur'an on environment protection namely by planting trees. Students were also accustomed to separate different types of garbage in different bins. Environmental Education (EE) was a local content included in the curriculum. Its main purpose is to instill awareness of school community members on the importance of preserving the environment. The regular environmental activities at the school were keeping the cleanliness and no littering.

17. Social Awareness

It refers to attitude of always willing to help others and the society in need. Its indicators were showing empathy to classmates, conducting social events, keeping the unity of school and class society members. The implementation was carried out through teaching-learning process by comprehension of the verses in the holy Qur'an about the order to help the needy and the poor, as well as understanding the good deeds as a part of Islamic teachings. Students were accustomed to help other students' or families currently facing challenges of life by praying for them, visiting or showing condolence and providing them with social assistance. They were also encouraged to conduct social works for disadvantaged communities around the school or other actions like doing blood donation.

18. Responsibility

It refers to a person's attitude and behavior to carry out his tasks and obligations, either to himself, to the society, to the environment (natural, social and cultural), or to God Almighty. The indicators were the implementation of the regular cleaning schedule, active participation in the school activities, and giving suggestions about school problems. The implementation of character education here was teaching students the verses of the Qur'an about men and their duties in the world, the work ethics, Faith in the Judgment Day, and about inheritance. Also, students were supposed to be responsible in submitting school assignment on time. Another implementation is students' responsibility to do what they were ordered to, such as cleaning the classroom as scheduled.

From the above findings, it is found out that the characteristics of SMA Amanah students are that embodied in piety (taqwa), and transformed into their daily activities. The values were instilled through character education rooted in religion, Pancasila, culture and education. 
a. The process of internalizing the values of religious character which is within the main source of Islamic law that is al-Qur 'an.

1) To worship God sincerely as stated in Q.S. Al-Baqarah [2]: 21, 63, and Q.S. Al-'Arâf [7]: 171;

2) To implement the law in accordance with what pre-determined by Allah as described in Q.S. Al-Baqarah [2]: 179;

3) to do fasting in the month of Ramadan as stated in Q.S. Al-Baqarah, [183].

4) to continuously be on the path of Allah S.W.T. and must not follow religions and beliefs other than Islam as stated in Q.S. Al-An'âm, [6]: 153.

b. The process of building honesty as a strong character as mentioned in Q.S. At-Taubah, [9]: 119 which states that a moslem must be honest.

c. The process of internalizing values of tolerance, and it is described in the Qur'an that everyone could choose whatever religion they believe, as stated in Q.S. Al-Baqarah [2]: 256, Q.S. Al-Kâfirûn, [109]: 6 Q.S. Yûnus, [10]: 41, and Q.S. Al-Kahfi, [18]: 29.

d. The process of instilling disciplined character as mentioned in Q.S. AlBaqarah [2]: 238 which order moslems to build a strong and strict habit of taking prayers on time.

e. The process of teaching values of hardwork, as stated in Q.S. Al-Mulk, [67]: 15 which order all moslems to exert all his strength to make a living on earth.

f. The process of training creativity as mentioned in Q.S. Ar-Ra'du, [13]: 11 about someone's efforts to be the best as Allah would not change him unless he is willing to.

g. The process of building independency as stated in Q.S. Al-Mukminûn, [23]: 62 that no one would be tested beyond his ability, and everyone should work and act accordingly. Therefore, each individual must be independent in solving problems or something and not rely on others.

h. The process of developing democratic value as described in Q.S. AlHujarât, [49]: 13 about someone's freedom to be anything he wants to be, and Q.S. An-Nisâ [4]: 7 about the justice in the system of inheritance.

i. The process of training curiosity as mentioned in Q.S. Ali Imrân [3]: 190 and Q.S. Adh-Dzâriyât, [51]: 20-21 that there are a lot of lessons in the creation of the universe for those who strive to know.

j. The process of building nationalism and patriotism as Q.S. Al-Hujarât, [49]: 13 states that men are encouraged to get to know each other and make friends.

k. The process of instilling values of appreciation as described in Q.S. Ali Imrân [3]: 148 that Islam appreciate good deeds by giving rewards. 
1. The process of habituating a friendly character as mentioned in Q.S. AsShûra, [42]: 38 and Q.S. Ali Imrân [3]: 159 about discussion and teamwork to solve problems.

$\mathrm{m}$. The process of teaching the values of peace loving as stated in Q.S.AlHashr, [59]: 23 about being peacemakers and Q.S. Al-Mâidah, [5]: 2 about helping each other in virtue.

n. The process of teaching to love reading as told in Q.S. al-'Alaq, [96]: 1-4 about how Allah orders the believers to read.

o. The process of teaching students to care for the environment as described in Q.S.Al-Baqarah [2]: 11 and Q.S. Al-A'râf, [7]: 56 that human beings are not allowed to do destruction.

p. The process of teaching students to have social awareness as mentioned in Q.S. Ali Imrân [3]: 110 that men must do good deeds and Q.S. AnNisâ [4]: 36 that men must treat everyone well especially their parents.

q. The process of training the responsible character as stated in Q.S. AlIsrâ, [17]: 36 about always being cautious in doing things.

Character education at the school had been built in the students. They were able to integrate the knowledge gained in the classroom and in the school society. They did not involve in juvenile delinquency or any type of crime. They tried to implement what they learned at school that these acts were forbidden by the religion. It was realized that character building needed to be forced before the students got used to apply it in everyday life. They were able to apply the results of two relationships: with Allah (bablum minallâh) and with other people (bablum min an-nâs).

Furthermore, the learning atmosphere created by pesantren-based SMA Amanah was the Islamic educational environment which attempted to apply the six values of life. They are as follows:

1. Teological value (value of divinity)

In Islam, God is Allah and there are three stages of belief: faith, Islam and charity (ibsân). Faith means that moslem believes that there are six pillars of faith: the belief in God, the belief in angel, the belief in His Books, the belief in the Prophets and the Messengers, the belief in the judgment day, and the belief in destiny (qadla and qadar).

Islam means acknowledging and practicing the five pillars of Islam: testifing that there is no God but Allah and Mohammed is his messenger, doing the prayers, making the mandatory charity, fasting during Ramadan month, and conducting pilgrimage if they could afford it.

Ihsan has two meanings. The first is the relationship with the Creator; it is that Moslems pray as if they see Him, and if they are not, (be sure) He sees. The second is the relationship with God's other 
creations; it is that Moslems should do good deeds to others and to the environment.

2. Physical/physiological value

It means to optimize physical functions in order to live this life. Islam teaches Moslems to have healthy lifestyle. This is an effective way to avoid getting sick. Cleanliness, for example, is emphasized in Islam and is considered as a reflection of one's faith. The order to clean little dirt (hadast), take mandatory showers (janâbat), and brush teeth (siwâk) show how Islam is indeed very concerned about physical cleanliness. In ablutions (wudlu), for instance, a Moslem would immediately wash his hands and face.

3. Ethical value

It refers to respectful, trustworthy, and fair character. This value is closely related with good attitude/akhlâq.

4. Aesthetic value

It includes harmony, attraction, beauty, and love. Allah created everything in the universe not only with each functions but also with a high degree of orderliness, harmony, and beauty.

5. Logical value

It deals with the processes of thinking, understanding, and remembering. In Islam, thinking ability has a high position and serves in the development of science, culture and Islamic teachings.

6. Teleologic value

It is related to the benefits, effectiveness, efficiency, productivity and accountability in every aspect of life. Islam is very concerned with the values of the social impacts (maslahat) and advantages of every rule and teaching for the people and the environment.

\section{Problems Encountered in the Implementation of Character Education in SMA Amanah and the Solutions}

Based on the interviews conducted, it is found out that the general problems in dealing with the implementation of character education were:

1. Students' heterogeneous background; they came from different regions with different customs, different norms and values were brought along with their arrivals. Consequently, it took a long time for the character education process to take place. Islamic character education should be able to scrape the negative local characters, such as the habit of speaking loudly and bluntly that could offend people, or the habit of dressing improperly in public places. Efforts were being made to address the diversed cultural backgrounds of prospective students. It was by conducting an orientation program (Khutbat al-Arsy) for new students. 
This activity was carried out by students and teachers at the school. New students were introduced to the culture and Islamic characters practiced by the senior students in the boarding schools. The school displayed wise words and quotes on the walls all over the school in order to motivate the students. This cultural diversity would eventually converge and emerge in Islamic characters.

2. Students' financial capacity; not all students of this school came from wealthy families. Some of them belonged to poor families and even almost decided to stop going to school due to lack of financial support. For those who struggled to overcome financial problems, the school tried to call their parents and have a talk with them. Several solutions were offered with respect to their capacity. They were offered to pay half of the tuition, or in the worst case where they really could not afford it the school would fully finance all the tuition and living cost. The second option applied in one condition that the respective student should work in the boarding school for a few years after they graduated.

3. Student psychological problem; some students have problems in following school lessons and extracurricular activities. It turned out that most of them had problems at home, such as divorcing parents and some others. For those with psychological problems coming from the family, the school attempted some possible solutions. Their parents were invited to come to the school, or if necessary, representatives of the schools would visit them at home to discuss the matter and possibly overcome it and get the respective student's focus in learning back.

4. Bad impact of information and communication technology; the influence of science and technology developments is accelerated by the presence of the internet, mobile phones and other electronic equipments. However, they might bring negative impacts on the students, as the gadgets could distract their concentration to study. Efforts are made to overcome the negative effects of electronic equipment on the students' character. The school made a strict rule about the use of gadgets during the lessons or other learning activities. Regular or incidental search for forbidden electronic items and other valuable things were conducted if necessary, targeting students' school bags or their bedrooms. The school also anticipated students' possibly-changed behavior post-holiday by giving them lectures on wisdom. The schools also kept reminding parents concerning their policy to prohibit students to bring electronic equipments to schools.

5. Parents' complaint on the living cost; some parents complained that the living cost in the boarding school was different from the information they received. The living cost turned out so high because the young 
students who were away from parental supervision were not able to manage their own finance. They tend to spend too much of their allowance. One of the causes was that food vendors often came to their room and directly offered them many kinds of food. To solve this problem, the school and dormitory committee applied strict rules. Students were not allowed to bring too much money, and were only allowed to buy snacks in the decided moments. To avoid food vendors from entering the dormitory, the committee built a fence to separate the school complex and the neighborhood. The school gate was always attended by security guards responsible directly to the principal.

6. Too strict rules led to boredom; the strict rules were applied in the boarding school and there was minimum facility in the dormitory where many students assumed that the number of occupants of each bedroom was too many. This condition might cause boredom for the students. Eventually, some students sneaked out of the school or dormitory just to get some fresh air and seek entertainment. That some students came late to the class because they fell asleep after shubh (morning) prayer also happened a lot. Efforts are made to overcome boredom and burnout of staying in dormitory for students. The school designed a soul empowering program through lectures and discussions. The number and variations of students' activities such as sports, arts, scouting and life-skill trainings were also increased. Hopefully, these activities could keep students' desire to sneak out or to go home. It is expected that these program could make students felt like home.

7. Theft of students' belonging; those who belonged to wealthy families usually had gadgets and other electronic devices (such as mobile phone, camera, tape recorder, etc.). This condition caused problem of theft, as not everyone had the privilege of buying anything the wanted or needed. Students sometimes lost their money or valuable belongings. Efforts are made to overcome these cases. Since the first day of school, all teachers and school board always emphasized that all students should abide by the rules. Warnings and notices were also displayed all over the school. However, theft still occurred. The school eventually assigned guards in many parts of the school complex, especially during teaching-learning process.

8. Environmental hygiene; complaints were submitted by parents concerning with the garbage dumped in each dormitory. It was often exceeded the capacity of the dumpsters and kept in too long time. It caused unpleasant smell and invited flies which could harm students' health. To overcome this, the schools promoted and encouraged students to sort the garbage out based on its category: plastic, paper, metal, and 
food waste, and to put them into different container/bag, so other people could make use of them.

9. The availability of water for sanitation; every dry season came along with, water shortage occurred. Students found it difficult to fulfill their needs for sanitation. To solve this problem, the school and teachers taught the students to conduct tayammum (self-cleaning without water) so they could still perform the prayers.

\section{CONCLUSION}

The principal's policies regarding the practice of character education were related to local and global-based education in boarding school. The programs included Tabfìdz, al-Qur'ân, Arabic language, life skills, and students' community services. The aims of character education in this regard was that the youth as the next generation would be able to appreciate, understand, and practice the values and norms of Islam and Pancasila. All the experience, knowledge, abilities, skills and background were expected to lead them to fully actualize the values and norms in their life in the future. To implement character education, the school creates supporting environment which was established through training, teaching, directing, and role-modeling. These factors have very strong influence on the students' character building. Pesantren graduates were the youths of Islam who were expected to have the power of science and charity. They were envisioned to have competence to carry out the integration of knowledge (science), values and attitudes (iman) and deeds ('amal) in life. Concerning students' scientific development, the school had facilitated them to become competent people. They were equipped with foreign language (Arabic and English) because language is a key to open their horizons, both behaviorally and scientifically.

\section{BIBLIOGRAPHY}

Zuhdi, D. (2009). Pendidikan Karakter, Yogyakarta: UNY, Press.

Zubaedi. (2012). Desain Pendidikan Karakter, Konsepsi dan aplikasinya dalam Lembaga Pendidikan, Jakarta: Kencana Prenada Media Group.

Sanusi, A. (2011). Makalab: Pola Karakter Indonesia, Bandung.

Imam A. G. (1994). Ibya' Ulumiddin seri IX Penerjemah: Moh. Zuhri, dkk., Semarang: CV. Asy Syifa. 